\title{
Docking studies of usnic acid and sodium usnate on SARS CoV-2 main protease and spike protein RBD Roopa Guthappa*
}

Independent Researcher, Gayathrinagar, Rajajinagar C block, Bangalore 560023

*To whom correspondence should be addressed E- Mail: roopag81@yahoo.com

\begin{abstract}
SARS CoV-2 a pandemic influenza like infectious disease emerged in December 2019 has spread throughout the world within few months. Scientists are trying their best to find medicine and vaccine. Usnic acid and its derivatives as herbal supplements are widely used as mouth wash, cosmetics, antiviral agents. In this study, usnic acid and its derivativesodium usnate in comparison with favipiravir are docked with main protease and spike protein RBD 6M0J of SARS Cov-2. Usnic acid and sodium usnate exhibit better binding affinities for main protease and spike RBD. The data has been compared with favipiravir. Favipiravir, usnic acid, sodium usnate shows binding affinity of $\mathbf{- 4 . 2 5}, \mathbf{- 8 . 0 5}$ and $\mathbf{- 8 . 5 5}$ $\mathrm{kcal} / \mathrm{mol}$ respectively with main protease. While favipiravir, usnic acid and sodium usnate exhibit binding affinities of $\mathbf{- 4 . 2 5}, \mathbf{- 6 . 0 2}$ and $\mathbf{- 6 . 5 3} \mathrm{kcal} / \mathrm{mol}$ with spike RBD respectively. One of the interesting features is that the inhibition constant values of usnic acid is $1.27 \mu \mathrm{M}$ and sodium usnate is $539.86 \mathrm{nM}$ in comparison to favipiravir $(764.13 \mu \mathrm{M})$ with main protease.
\end{abstract}

Keywords: SARS-CoV-2, usnic acid, sodium usnate, main protease, spike protein RBD Introduction

SARS CoV-2 a pandemic influenza like infectious disease emerged in December 2019 spread throughout world within few months. It has resulted in half million deaths worldwide. By forcing countries to lockdown for weeks to months it has created an economic depression. SARS CoV-2 has taken full priority not only in medical but in every aspects of life. Hence scientists are trying their best to find medicine and vaccine. The coronavirus main protease $\left(\mathrm{M}^{\mathrm{pro}}\right)$ plays a major role in viral gene expression and replication which has become a main target for developing anti-CoV 
drug. Hence molecular docking studies with main protease has open up a gateway for further studies regarding its potential use as medicine and drug design [1-2].

SARS CoV-2 consists of mainly four structural proteins: Spike (S), envelope (E), membrane (M) and nucleocapsid $(\mathrm{N})$ proteins of which, spike protein attaches to host cell membrane to infuse viral component into it. Hence it plays a vital role in the initial steps of viral binding. In spike protein, especially receptor binding domain is of interest as it binds strongly to human angiotensin-converting enzyme 2 (ACE2) receptors promoting a way for viral replication [3]. Several drugs have been tested for SARS-CoV-2 of which prominently used ones are hydroxychloroquinone, remdesivir and favipiravir [4-6]. Even though the above drugs have been used their efficacy in treatment is not up to the mark. Scientists have screened the existing and FDA approved drugs for their binding ability to SARS CoV-2 using molecular docking studies. Also using molecular docking and dynamic studies, several phytochemical components have also been examined for their utility in the treatment of SARS CoV-2. Usnic acid a furandione found naturally in lichens, a fungus integrated with algae, an herbal supplement is widely used in cosmetic, deodorants, toothpaste, mouth wash, medicinal creams, lozenges [7-9]. Traditionally it is used in herbal medicines as analgesic, antiviral, antibacterial, antifungal, anti-inflammatory, anticoagulant, antipyretic, headache, oral hygiene, antiparasitic etc [10-13]. In Chinese traditional medicines it is used in treatment of bronchitis and for thyroid cancers [9]. Also used in native american medicine and european traditional medicines. Sodium usnate being used in anti dandruff products, deodorant and acne-prone skin cosmetic applications when taken about 300-1350 mg orally daily for weeks has led to severe hepatotoxicity [14-15]. Its toxicity is linked with to its hydrophobic characteristics and low solubility in aqueous medium at higher dosage. Studies have been conducted to improve its bioavailability to reduce the dosage, toxicity and increase its solubility. Recently the application of usnic acid and its derivatives has increased significantly in biological and pharmaceutical field [16-19]. It has been demonstrated that usnic acid inhibits inflammatory response and prooxidant damage in pulmonary tissue mice infected with pulmonary fibrosis as a therapeutic against pulmonary disease [16]. Studies on usnic acid encapsulated into lipid-based, polymeric and non-organic micro- and/or nanocarriers, as potential drug delivery systems are some efforts are in process to overcome its limitations [12, 20]. Sodium usnate, copper usnate, potassium salt of usnic acid are some of its derivatives. In this article, usnic acid and sodium usnate are docked with SARS CoV-2 main protease and SARS 
CoV-2 RBD spike protein. Favipiravir is currently used in medication of SARS COV-2 has been compared with usnic acid and its derivatives using docking studies. The results show that usnic acid and its derivatives bind to both main protease and spike protein active sites of SARS Cov-2 with better affinity and exhibit lower inhibition constant in comparison to favipiravir.

\section{Methods}

\section{Molecular docking studies}

Receptor-binding domain/RBD of the spike protein of SARS-CoV-2 (PDB ID. 6M0J) and Proteins/Macromolecules SARS COV 2 3CLpro/Mpro (PDB ID. 6LU7) structures were retrieved from website https://www.rcsb.org/ in PDB format. Ligand molecules-usnic acid and sodium usnate in SDF formats were collected from PubChem database. Main protease 6LU7, RBD protein 6M0J and ligands were separately prepared. Amino acids His-41, Cys-145 and Gln-189 were chosen as active sites for main protease from the reported data and confined in the grid box of size $60 \times 60 \times 60$ whereas amino acids LYS417, TYR 449, TYR 489, GLN 493, TYR 505 were targeted to spike protein RBD as these amino acids are important in ACE-2 binding [2,3]. Binding energies were optimized using search genetic algorithm and Lamarckian genetic algorithm using Auto Dock tools. The results were analyzed using UCSF chimera software.

\section{Results and discussion}

Table 1 shows molecular structure, molecular weight and rotatable bonds of ligands used to dock with SARS CoV 2 protein and follows Lipinski's rule. Docking studies were carried out on SARS CoV-2 main protease and spike RBD protein with usnic acid, sodium usnate and favipiravir separately. Among the given conformations of protein ligand interaction only the top ranked binding energy for the known binding sites was considered. In Table 2 is given the summary of the docking results.

Usnic acid, sodium usnate and favipiravir binds to the active sites well for both main protease and spike protein RBD. Usnic acid binds to HIS 163 similar to favipiravir and also forms bond with CYS 145 for main protease, whereas sodium usnate binds with CYS145, SER144, LEU141 with main protease.

While, usnic acid binds to GLY 496, TYR 449, AGR403, GLN 493, sodium usnate to TYR449, GLY 496 and favipiravir to GLN 493 and SER 494 in spike protein RBD. 
During the docking of ligand with the main protease/spice RBD, the sum of the energies of ligand and receptor should be greater than the total energy when bound together. This difference gives us binding free energy and more negative the binding energy, deeper its potential energy well, and better binding action [21].

Binding affinities of usnic acid and sodium usnate are -8.05 and $-8.55 \mathrm{kcal} / \mathrm{mol}$ whereas for favipiravir it is $-4.25 \mathrm{kcal} / \mathrm{mol}$ on docking with main protease. While the binding affinities of usnic acid and sodium usnate are -5.62 and $-6.27 \mathrm{kcal} / \mathrm{mol}$ respectively compared to favipiravir ($4.25 \mathrm{kcal} / \mathrm{mol}$ ) with spike protein RBD. Tables 3 and 4 show the statistical mechanical analysis data and estimated energies of usnic acid, sodium usnate and favipiravir with main protease and spike protein RBD respectively. Figure 1 shows usnic acid, sodium usnate and favipiravir binding with main protease 6LU7 visualized using autodock tools and Chimera. Figure 2 shows usnic acid, sodium usnate and favipiravir with spike protein RBD 6M0J.

Inhibition constant $\mathrm{K}_{\mathrm{i}}$ values provide information about the biochemical activities of the ligands. Lower the inhibition constant value better will be the ligand efficacy. In this regard, usnic acid and sodium usnate shows lower inhibition constants compared to favipiravir as seen in table 2 . Sodium usnate shows lowest inhibition constant of $539.86 \mathrm{nM}$, usnic acid with $1.27 \mu \mathrm{M}$ compared to favipiravir having $764.13 \mu \mathrm{M}$ indicating that sodium usnate has better binding efficiency for main-protease. While for spike protein RBD, inhibition constants of sodium usnate and usnic acid are $16.40 \mu \mathrm{M}$ and $38.75 \mu \mathrm{M}$ respectively when compared to favipiravir (772.40 $\mu \mathrm{M})$.

Usnic acid and sodium usnate shows better binding abilities to both main protease and spike protein RBD 6M0J compared to favipiravir. Although sodium usnate being toxic is not recommended for internal usage. But it can be used as external disinfectants as it showed a very low inhibition constant along with good binding affinity. Also, usnic acid and its derivatives (potassium usnate) can be further explored for SARS CoV 2. 
Table 1. Ligands used to dock with SARS COV 2 proteins.

\begin{tabular}{|c|c|c|c|c|}
\hline $\begin{array}{l}\text { Ligand/ } \\
\text { Compond }\end{array}$ & Molecular structure & Formula & $\begin{array}{l}\text { Molecular } \\
\text { weight }\end{array}$ & $\begin{array}{l}\text { Rotatable } \\
\text { bonds }\end{array}$ \\
\hline $\begin{array}{l}\text { Usnic } \\
\text { acid }\end{array}$ & & $\mathrm{C}_{18} \mathrm{H}_{16} \mathrm{O}_{7}$ & $\begin{array}{l}344.3 \\
\mathrm{gmol}^{-1}\end{array}$ & 4 \\
\hline $\begin{array}{l}\text { Sodium } \\
\text { usnate }\end{array}$ & & $\mathrm{C}_{18} \mathrm{H}_{15} \mathrm{NaO}_{7}$ & $\begin{array}{l}366.3 \\
\text { gmol }^{-1}\end{array}$ & 3 \\
\hline favipiravir & & $\mathrm{C}_{5} \mathrm{H}_{4} \mathrm{FN}_{3} \mathrm{O}_{2}$ & $\begin{array}{l}157.1 \\
\mathrm{gmol}^{-1}\end{array}$ & 2 \\
\hline
\end{tabular}


Table 2. Binding affinity, entropy, internal energy, bonds formed and estimated inhibition constants for ligand-protein interactions.

\begin{tabular}{|c|c|c|c|c|c|}
\hline $\begin{array}{l}\text { Compound } \\
\text { name }\end{array}$ & $\begin{array}{l}\text { Protein or } \\
\text { macromolecule }\end{array}$ & $\begin{array}{l}\text { Binding } \\
\text { affinity } \\
\text { (kcal/mol) }\end{array}$ & $\begin{array}{l}\text { Entropy } \\
(\AA)\end{array}$ & Bonds formed & $\begin{array}{l}\text { Estimated } \\
\text { Inhibition } \\
\text { Constant, } K_{\mathbf{i}}\end{array}$ \\
\hline Favipiravir & 6LU7 & -4.25 & 0.53 & $\begin{array}{ll}\text { ASN 142 } & 2.093 \AA \\
\text { HIS 163 } & 1.842 \AA \\
\end{array}$ & $764.13 \mu \mathrm{M}$ \\
\hline Usnic acid & 6LU7 & -8.05 & 0.22 & $\begin{array}{lr}\text { His 163 } & 1.893 \AA \\
\text { CYS 145 } & 3.418 \AA \\
\end{array}$ & $1.27 \mu \mathrm{M}$ \\
\hline $\begin{array}{l}\text { Sodium } \\
\text { usnate }\end{array}$ & 6LU7 & -8.55 & 0.27 & $\begin{array}{lr}\text { CYS145 } & 1.885 \AA \\
\text { SER144 } & 1.966 \AA \\
\text { LEU141 } & 1.857 \AA\end{array}$ & $539.86 \mathrm{nM}$ \\
\hline Favipiravir & $6 \mathrm{M} 0 \mathrm{~J}$ & -4.25 & 0.41 & $\begin{array}{ll}\text { GLN 493 } & 2.000 \AA \\
\text { SER 494 } & 2.075 \AA\end{array}$ & $772.40 \mu \mathrm{M}$ \\
\hline Usnic acid & $6 \mathrm{M} 0 \mathrm{~J}$ & -6.02 & 0.65 & $\begin{array}{cc}\text { GLY 496 } & 2.364 \AA \\
\text { TYR 449 } & 1.717 \AA \\
\text { AGR403 } & 1.957 \AA \\
\text { GLN 493 } & 1.847 \AA\end{array}$ & $38.75 \mu \mathrm{M}$ \\
\hline $\begin{array}{l}\text { Sodium } \\
\text { usnate }\end{array}$ & $6 \mathrm{M} 0 \mathrm{~J}$ & -6.53 & 0.56 & $\begin{array}{ll}\text { TYR449 } & 1.986 \AA \\
\text { GLY 496 } & 2.401 \AA\end{array}$ & $16.40 \mu \mathrm{M}$ \\
\hline
\end{tabular}


Table 3. Statistical mechanical analysis of ligand protein interactions

\begin{tabular}{|l|l|l|l|l|l|l|}
\hline & \multicolumn{3}{|c|}{ Docked with 6LU7 } & \multicolumn{3}{c|}{ Docked with 6M0J } \\
\hline $\begin{array}{l}\text { Statistical } \\
\text { mechanical } \\
\text { analysis } \\
(\mathrm{T}=298.15 \mathrm{~K})\end{array}$ & Favipiravir & \multicolumn{1}{|c|}{$\begin{array}{c}\text { Usnic } \\
\text { acid }\end{array}$} & $\begin{array}{c}\text { Sodium } \\
\text { usnate }\end{array}$ & Favipiravir & $\begin{array}{c}\text { Usnic } \\
\text { acid }\end{array}$ & $\begin{array}{c}\text { Sodium } \\
\text { usnate }\end{array}$ \\
\hline $\begin{array}{l}\text { Partition } \\
\text { function, Q }\end{array}$ & 10.07 & 10.13 & 10.14 & 10.07 & 10.10 & 10.11 \\
\hline $\begin{array}{l}\text { Free energy, A } \\
\text { (kcal/mol) }\end{array}$ & -1368.38 & -1372.14 & -1372.38 & -1368.35 & -1369.86 & -1370.51 \\
\hline $\begin{array}{l}\text { Internal energy, } \\
\text { U (kcal/mol) }\end{array}$ & -4.14 & -7.90 & -8.14 & -4.11 & -5.62 & -6.27 \\
\hline $\begin{array}{l}\text { Entropy, S } \\
\text { (kcal/mol/K) }\end{array}$ & 4.58 & 4.58 & 4.58 & 4.58 & 4.58 & 4.58 \\
\hline
\end{tabular}

Table 4. Estimated energy analysis for protein ligand interactions

\begin{tabular}{|l|l|l|l|l|l|l|}
\hline & \multicolumn{3}{|c|}{ Docked with 6LU7 } & \multicolumn{3}{c|}{ Docked with 6M0J } \\
\cline { 2 - 7 } & Favipiravir & Usnic acid & $\begin{array}{l}\text { Sodium } \\
\text { usnate }\end{array}$ & Favipiravir & Usnic acid & $\begin{array}{l}\text { Sodium } \\
\text { usnate }\end{array}$ \\
\hline $\begin{array}{l}\text { Final Intermolecular Energy } \\
\text { (kcal/mol) }\end{array}$ & -4.55 & -9.24 & -9.45 & -4.54 & -7.21 & -7.42 \\
\hline $\begin{array}{l}\text { vdW + Hbond + desolv Energy } \\
\text { (kcal/mol) }\end{array}$ & -4.49 & -9.31 & -9.24 & -4.45 & -6.90 & -7.40 \\
\hline $\begin{array}{l}\text { Electrostatic Energy } \\
\text { (kcal/mol) }\end{array}$ & -0.06 & +0.07 & -0.20 & -0.09 & -0.31 & -0.02 \\
\hline $\begin{array}{l}\text { Final Total Internal Energy } \\
\text { (kcal/mol) }\end{array}$ & +0.02 & -0.91 & +0.03 & +0.02 & -0.61 & -0.17 \\
\hline $\begin{array}{l}\text { Torsional Free } \\
\text { Energy(kcal/mol) }\end{array}$ & +0.30 & +1.19 & +0.89 & +0.30 & +1.19 & +0.89 \\
\hline $\begin{array}{l}\text { Unbound System's Energy } \\
\text { (kcal/mol) }\end{array}$ & +0.02 & -0.91 & +0.03 & +0.02 & -0.61 & -0.17 \\
\hline
\end{tabular}



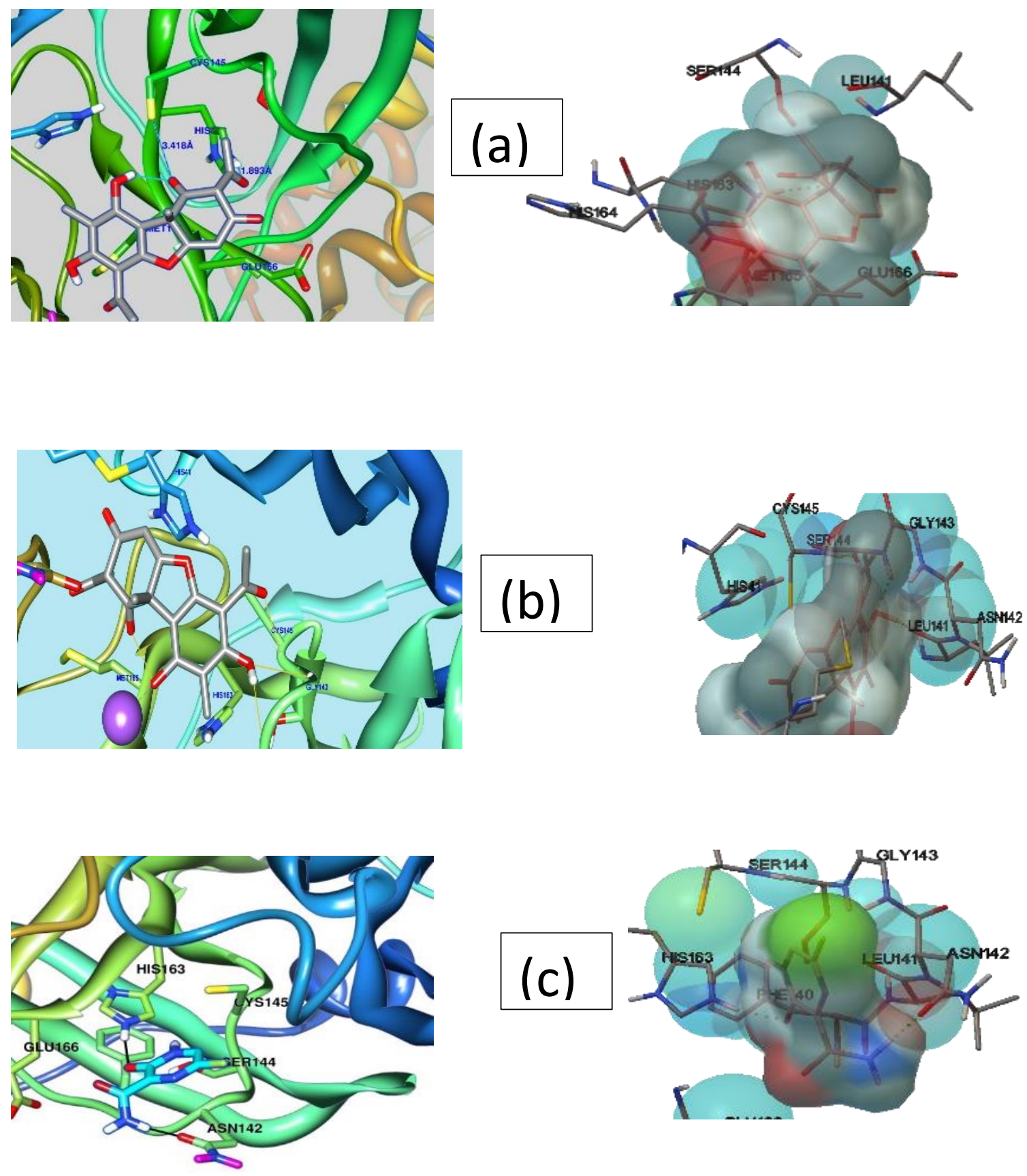

Figure 1. (a) Usnic acid, (b) sodium usnate and (c) favipiravir interaction with main protease 6LU7. 

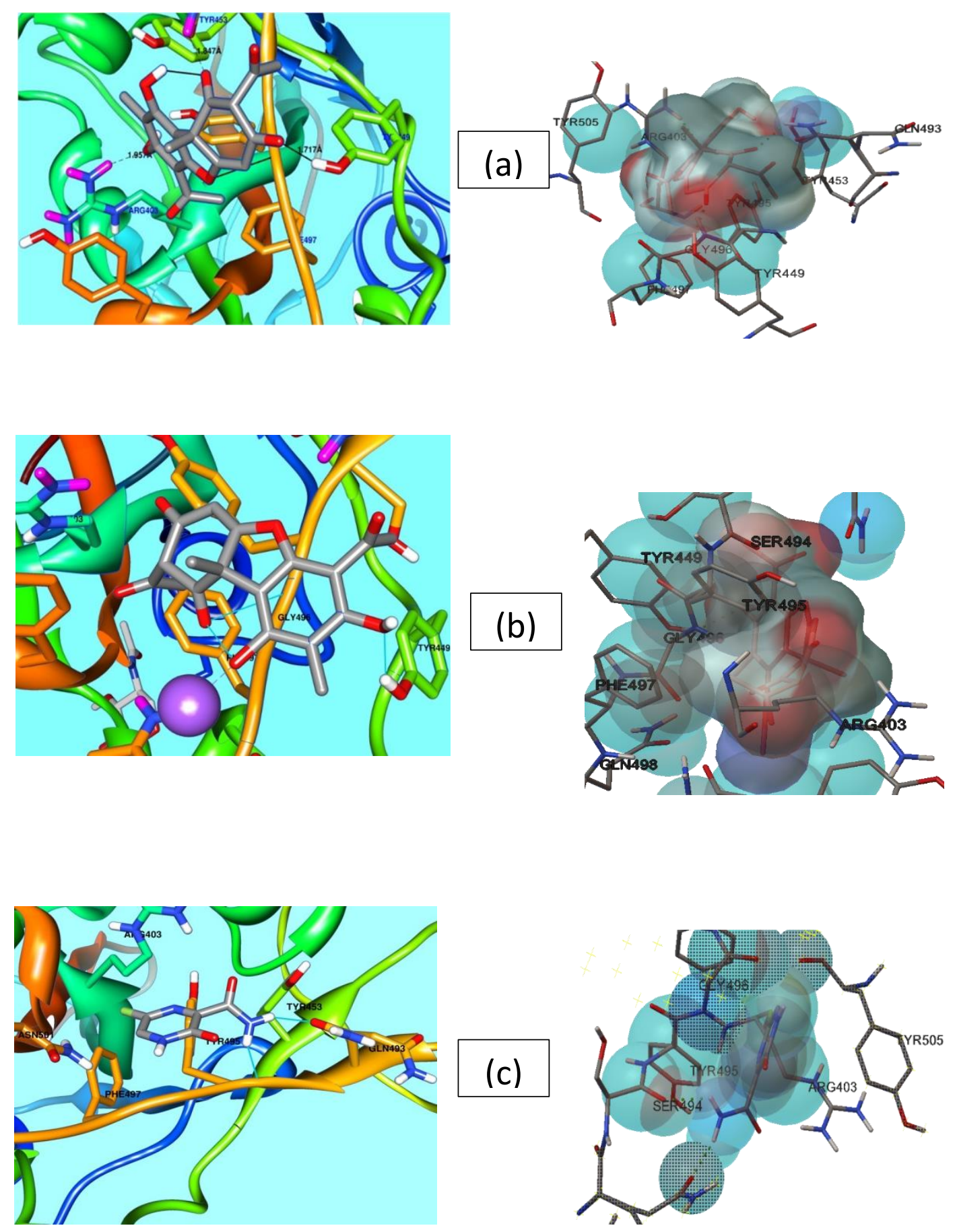

Figure 2. (a) Usnic acid, (b) sodium usnate and (c) favipiravir with spike protein RBD 6M0J.

\section{Conclusion}

Usnic acid products and their herbal supplements have been used for long time due to their medicinal values. We have reported that usnic acid and its derivative can effectively bind to on 
SARS-CoV-2 main protease and spike protein RBD 6M0J based on docking studies. Binding affinity values and inhibition constant values are better for SARS coV-2 main protease and spike protein RBD 6M0J. Sodium usnate even though has been reported to be toxic, its inhibition constant value is in nanomolar range demonstrating that salts of usnic acid can be effective in binding to both main protease and spike protein. Also, usnic acid derivatives with more bioavailability and solubility may be explored for their potentiality as drug molecules towards SARS CoV-2 and clinical trials may provide supporting data.

\section{Conflict of interest}

Author declares no conflict of interest Compliance with Ethical Standards.

\section{Compliance with Ethical Standards}

This article does not contain any studies involving animals or human participants.

\section{References}

[1] Jin, Z., Du, X., Xu, Y., Deng, Y., Liu, M., Zhao, Y., Zhang, B., Li, X., Zhang, L., Peng, C., Duan, Y., Yu, J., Wan,g L., Yang, K., Liu, F., Jiang, R., Yang, X., You, T., Liu, X., Yang, X., Bai, F., Liu, H., Liu, X., Guddat, L.W., Xu, W., Xiao, G., Qin, C., Shi, Z., Jiang, H., Rao, Z. and Yang, H., Structure of Mpro from covid-19 virus and discovery of its inhibitors. Nature, 2020, https://doi.org/10.1038/s41586-0202223-y

[2] L. Zhang, D. Lin, X. Sun, U. Carth et al. (2020) Crystal structure of Sars-Cov2 main protease provides a basis for design of improved $\square$-ketomide inhibitors. Science 368(6489), 409-412.

[3] J. Lan, J. Ge, J. Yu, S. Shan, H. Zhou, S. Fan, Q. Zhang, X. Shi, Q. Wang, L. Zhang and X. Wang (2020). Structure of the SARS-CoV-2 spike receptor-binding domain bound to the ACE2 receptor. Nature, 581, 215-220.

[4] Xu, M., Wang, X., Zhang, H., Hu, H., Li, Y., Hu, Z., Zhong, W. and Wang, M., Hydroxychloroquine, a less toxic derivative of chloroquine, is effective in inhibiting SARS-CoV-2 infection in vitro. Cell Discovery, 2020, 6, 16. https://doi.org/10.1038/s41421-020-0156-0.

[5] Wang, M., Cao, R., Zhang, L., Yang, X., Liu, J., Xu, M., Shi, Z., Hu, Z., Zhong, W., Xiao, G. and Liu, J., Remdesivir and chloroquine effectively inhibit the recently emerged novel coronavirus (2019$\mathrm{nCoV}$ ) in vitro. Cell Res., 2020, 30, 269-271.

[6] E.A. Coomes and H. Haghbayan (2020) Favipiravir, an antiviral for COVID-19? Journal of antimicrobial chemotherapy 75(7), 2013-2014.

[7] M. Cocchietto, N. Skert, P.L. Nimis and G. Sava (2002). A review on usnic acid, an interesting natural compound. Naturwissenchaften, 89, 137-146.

[8] M. Ghione, D. Parrello and L. Grasso (1988). Usnic Acid Revisited, Its Activity on Oral Flora. Chemioterapia, 7(5), 302-305. 
[9] C. Hobbs (1986). Usnea: The herbal antibiotic and other medicinal lichens. Herbs and health series Paperback - January 1, 1986.

[10] P. Scrippa, G. Scambia, V. Masciul , F. Battaglia, E. Foti, R. Lopez, P. Villa, M. Malecore, and S. Mancuso (1999). A zinc sulfate and usnic acid preparation used as post- surgical adjuvant therapy in genital lesion by human papillomavirus. Minerva Ginecol.,

$51,255-260$.

[11] O.A. Luzina and F.S. Nariman (2018). Usnic acid and its derivatives for pharmaceutical use: a patent review (2000-2017). Expert Opin Ther Pat., 28(6), 477-491.

[12] S.M. William, A.P. Francis, T. Devasena (2014). In situ isolation and characterization of nano-usnic acid for medical applications. International Journal of Pharmacy and Pharmaceutical Sciences, 16(6)

[13] D.N. Sokolova, V.V. Zarubaevb, A.A. Shtrob, M.P. Polovinkaa, O.A. Luzinaa, N.. Komarovaa, N.F. Salakhutdinova, O.I. Kiselev (2012). Anti-viral activity of (-)- and (+)-usnic acids and their derivatives against influenza virus A(H1N1). Bioorganic \& medicinal chemistry letters 22, 7060-7064.

[14] T.L. Fong (2002). Severe hepatotoxicity associate with the dietary supplement LipoKinetix. Annals of Internal Medicine 13 (8): 590-595.

[15] J.D Estes, D. Stolpman, A. Olyaei, C.L. Corless, J.M. Ham, J.M. Schwartz, S.L. Orloff (2003). High prevalence of potentially hepatotoxic herbal supplement use in patients with fulminant hepatic failure. Archives of Surgery, 138(8), 852-858.

[16] X.-Q. Huang, G.-X. Ai, X.-H. Zheng, H.-J. Liao (2019). Usnic acid ameliorates bleomycin-induced pulmonary fibrosis in mice via inhibition of inflammatory responses and oxidative stress. Tropical Journal of Pharmaceutical Research, 18(12), 2563-2569.

[17] A. Galanty, P. Paśko and I. Podolak (2019). Enantioselective activity of usnic acid: a comprehensive review and future perspectives. Phytochemistry Reviews, 18, 527-548.

[18] Y. Yang, W. K. Bae, J.-Y. Lee, Y. J. Choi et al. (2018). Potassium usnate, a water-soluble usnic acid salt, shows enhanced bioavailability and inhibits invasion and metastasis in colorectal cancer. Nature Research Journal, 8, Article number: 16234.

[19] G.-K. Beata, G. Katarzyna and H.-A. Anna (2019). Usnic acid derivatives as cytotoxic agents against cancer cells and the mechanisms of their activity. Current Pharmacology, 5, 429-439.

[20] A. Zugic, V. Tadic, and S. Savic (2020) Nano- and microcarriers as drug delivery systems for unic acid: Review of literature pharmaceutics, 12(2), 156.

[21] X. Du, Y. Li, Y.-L. Xia, S.-M. Ai, J. Liang, P. Sang, X.-L. Ji, and S.-Q. Liu. (2016). Insights into protein-ligand interactions: Mechanisms, models, and methods. Int J Mol Sci., 17(2), 144. 